\title{
Relationship between plasma and uterine oestradiol in pseudopregnant rabbits
}

\author{
S. Batra, Ch. Owman*, N.-O. Sjöberg and G. Thorbert \\ Department of Obstetrics and Gynecology, University Hospital, S-221 85 Lund, and \\ ${ }^{*}$ Department of Histology, University of Lund, S-223 62 Lund, Sweden
}

\begin{abstract}
Summary. Plasma oestradiol concentrations did not change during hCG-induced pseudopregnancy except for a slight increase on Day 18. However, a marked decline was observed in tissue oestradiol on Day 3 whether expressed on the basis of tissue wet weight or protein. The lowest concentration was found at Day 6 but the Day 18 values were comparable to those of untreated controls.
\end{abstract}

\section{Introduction}

In experimental studies dealing with reproductive endocrinology the pseudopregnant rabbit is a frequently used model. Accordingly, considerable information has been presented on the secretion of oestradiol and progesterone (see Hilliard \& Eaton, 1971; Shaikh \& Harper, 1972) and on the peripheral plasma levels of progesterone (Hilliard, Scaramuzzi, Penardi \& Sawyer, 1974). However, relatively little quantitative information is available on oestradiol levels in peripheral plasma during rabbit pseudopregnancy, for it is generally believed that, unlike those of progesterone, there are few or no variations in plasma oestradiol concentrations.

Since plasma steroid levels may not necessarily reflect the concentrations in the target tissue and since it is reasonable to think that the biological activity will perhaps be governed by concentrations in the tissue, we have focused our attention in the present paper on relationships between plasma and tissue concentrations of oestradiol.

\section{Materials and Methods}

\section{Animals}

The 25 virgin albino rabbits weighing $2 \cdot 2-3.0 \mathrm{~kg}$ were fed freely with a mixed diet and tap water. Pseudopregnancy was induced in 20 animals by a single injection of 100 i.u. hCG (Gonadex: Leo, Sweden) into the ear vein and 5 untreated animals served as controls. The hCGinjected animals were divided into 4 groups of 5 animals each on the basis of the duration of pseudopregnancy and accordingly were killed by cervical dislocation 3,6,12 or 18 days after the injection. Blood was drawn from the left heart ventricle, and after centrifugation the plasma was stored frozen at $-18^{\circ} \mathrm{C}$ until assay. The uterus was dissected out, slit open and blotted dry. The ovarian part of one horn was pooled with the cervical part of the other and vice versa, thus providing two comparable tissue samples. One was used for the estimation of tissue oestradiol and the other for fluorometric determination of norepinephrine, which has been reported separately (Thorbert, Batra, Owman, Rosengren \& Sjöberg, 1976).

\section{Oestradiol assays}

Plasma. The procedure for radioimmunoassay was that described by Lindberg, Lindberg, Martinsson \& Johansson (1974). The antiserum was raised in sheep against oestradiol-17ß-6oxime conjugated with bovine serum albumin and used at a dilution of 1:100000. After 
extraction of $1 \mathrm{ml}$ plasma with diethyl ether, $0.1 \mathrm{ml}$ each of antiserum and $\left[{ }^{3} \mathrm{H}\right]$ oestradiol $\left(\left[2,4,6,7-{ }^{3} \mathrm{H}\right]\right.$ oestradiol $-17 \beta$, sp. act. $102 \mathrm{Ci} / \mathrm{mmol}$ : New England Nuclear) were added. The mixture was equilibrated at $4^{\circ} \mathrm{C}$ overnight. The unbound steroid was removed by addition of dextran-coated charcoal.

The data on the precision and accuracy of this method for the determination of oestradiol$17 \beta$ in the rabbit plasma were also obtained. Although the cross-reaction of the antiserum to oestradiol- $17 \alpha$ was only $0.7 \%$ (oestradiol $-17 \beta=100 \%$ ), it was $11 \%$ for oestrone which could not be ignored. We therefore checked for the interference, if any, by oestrone in the extracted plasma. The concentration of oestradiol in plasma extract before and after Sephadex LH-20 chromatography was compared. Sephadex LH-20 was allowed to swell overnight in developing solvent solution (methanol:benzene, 15:85 v/v). This suspension was transferred to glass columns $(1.1 \mathrm{~cm}$ i.d.) and packed to a gel height of $9 \mathrm{~cm}$. The solvent solution was allowed to run through the column for $30 \mathrm{~min}$ before the application of the sample. The dried residue of the ether extract of plasma was dissolved in $0.5 \mathrm{ml}$ solvent solution and $0.2 \mathrm{ml}$ of this was applied on the column and subsequently eluted. Simultaneously $0.2 \mathrm{ml}$ of the dissolved extract was taken into assay tube for direct determination of oestradiol without chromatography. Under the present conditions of chromatography $90 \%$ of oestradiol, as revealed by preliminary experiment using radioactive oestradiol, was eluted in the fraction between 12 and $20 \mathrm{ml}$. This system of chromatography is very effective in separating oestradiol-17 $\beta$ from oestrone and oestriol as well as from progesterone and 17 $\alpha$-hydroxyprogesterone (Powell \& Stevens, 1973). After evaporating the solvent, the oestradiol concentration in the samples was determined by the usual radioimmunoassay.

Uterine tissue. Uterine oestradiol values were determined by the method described by Batra (1976). After thawing, the tissue was chemically digested by a mixture of $\mathrm{NaOH}$ and sodium dodecyl sulphate (SDS) (Batra \& Bengtsson, 1976). Generally $2.5 \mathrm{ml}$ of the mixture were used per $\mathrm{g}$ wet weight of tissue and the digestion was complete within 2 to $6 \mathrm{~h}$. Removal of SDS was accomplished by Sephadex LH-20 gel chromatography, and $6 \mathrm{ml}$ of the eluate were collected. After evaporating and redissolving the eluate in ethyl acetate, a suitable amount (depending on the predicted concentration of oestradiol) was taken for radioimmunoassay. Recovery of unlabelled oestradiol- $17 \beta$ was found to be $94.5-99.5 \%$ and the coefficient of variation was $4.5 \%$ and $9.9 \%$ for two different pools of rabbit uterine tissue.

The sensitivity of the method, defined as the amount significantly different from zero at the $95 \%$ confidence limit was $5 \mathrm{pg}$. The blank values using $\mathrm{NaOH}$ and SDS were not distinguishable from zero.

Protein concentration in the digested tissue was determined by the method of Lowry, Rosebrough, Farr \& Randall (1951) using bovine serum albumin dissolved in the digestion mixture as standard.

Statistical analysis was by Student's $t$ test.

\section{Results}

The data on the recovery of different amounts of oestradiol added in plasma of non-pregnant rabbit are shown in Table 1 . The intra- and inter-assay coefficients of variation, with values ranging from 15 to $65 \mathrm{pg} / \mathrm{ml}$, were 9.87 and $16.2 \%$, respectively $(n=10)$. There was an excellent agreement in the concentration of oestradiol between chromatographed and non-chromatographed extracts of plasma samples (Table 2).

\section{Plasma oestradiol}

The levels of oestradiol in plasma changed relatively little during pseudopregnancy, except for a slight rise on Day 18 (Table 3). 
Table 1. Recovery of added oestradiol $(\mathrm{pg} / \mathrm{ml})$ in plasma from non-pregnant rabbit

\begin{tabular}{rccc}
\hline$n$ & Amount added & Amount recovered & \% recovery \\
\hline 9 & 20 & $20 \cdot 0 \pm 1.9$ & 100 \\
10 & 40 & $40.2 \pm 1.9$ & 99 \\
\hline
\end{tabular}

\section{Tissue oestradiol}

When expressed in terms of wet weight of tissue, oestradiol values declined rapidly, the levels being reduced to $29 \%$ of the Day 0 values by Day 3 of pseudopregnancy (Table 3). After Day 6 there was an increase which continued until Day 18, and values comparable to those of the controls were obtained. When tissue oestradiol concentrations were determined on the basis of protein content (Table 3), the pattern of changes during pseudopregnancy was similar, although the decrease was less marked.

Table 2. Comparison of oestradiol concentrations in chromatographed and non-chromatographed extracts of six different plasma samples

\begin{tabular}{ccc}
\hline & \multicolumn{2}{c}{ Oestradiol conc. (pg/ml) } \\
\cline { 2 - 3 } Sample No. & $\begin{array}{c}\text { Non-chromatographed } \\
\text { sample }\end{array}$ & $\begin{array}{c}\text { Chromatographed } \\
\text { sample }\end{array}$ \\
\hline 1 & 19 & 20 \\
2 & 21 & 21 \\
3 & 19 & 19 \\
4 & 29 & 24 \\
5 & 28 & 30 \\
6 & 25 & 24 \\
\hline
\end{tabular}

There was an overall good correlation $(r=0.83)$ between the values $(n=25)$ expressed on the basis of wet weight and that of protein (data not shown).

Table 3. Plasma and uterine oestradiol concentrations (mean \pm s.e.m. for 5 animals) in pseudopregnant rabbits

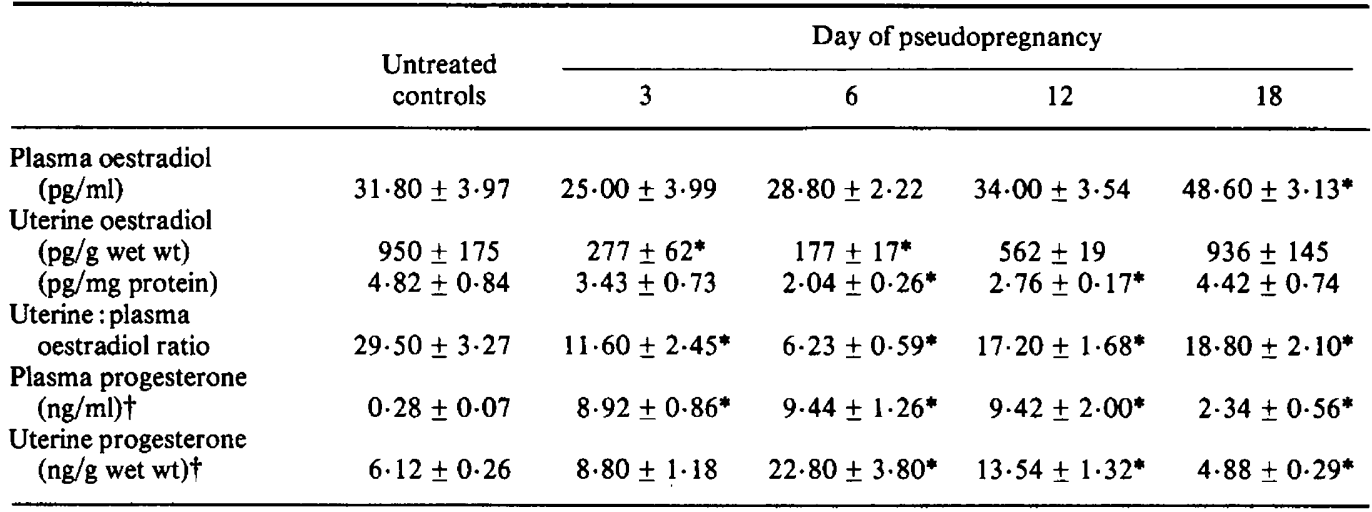

*Value significantly different from controls at $P<0.05$.

$\dagger$ Data from Thorbert et al. (1976). 


\section{Tissue/plasma oestradiol ratio}

Since the plasma oestradiol levels changed relatively little, the change in the ratio of tissue oestradiol (per g wet weight) to plasma oestradiol (per $\mathrm{ml}$ ) essentially reflected the alterations in tissue oestradiol values during pseudopregnancy (Table 3).

\section{Discussion}

Plasma oestradiol concentrations reported in the present study are in good agreement with those recently found by $\mathrm{Wu}$, Blasco, Flickinger \& Mikhail (1977) in the non-pregnant rabbit. The finding of relatively little change in plasma oestradiol concentrations during pseudopregnancy in the rabbit in general agrees with the data of Challis, Davies \& Ryan (1973) who studied changes in ovarian hormones in pregnant rabbits. Since plasma progesterone levels in pseudopregnancy (Hilliard et al., 1974; Thorbert et al., 1976) and in pregnancy (Challis et al., 1973) alter greatly, it must be concluded that there is no evident influence of progesterone on oestradiol secretion. This conclusion is supported by the data of Eaton \& Hilliard (1971) who found no change in ovarian oestradiol secretion between ovaries with and without corpora lutea.

It is therefore noteworthy that the present results show a considerable alteration in tissue oestradiol levels in pseudopregnancy, in spite of a relatively constant level of this steroid in the plasma. However, the levels of progesterone in plasma and tissue of pseudopregnant rabbits do alter considerably (Thorbert et al. 1976), although in an inverse relationship to those of tissue oestradiol (Table 3), and it is natural to ask whether plasma and/or tissue progesterone concentrations influence the tissue oestradiol levels and to what extent.

The lowest concentration of oestradiol in tissue, whether expressed in terms of protein or wet weight, was found at Day 6 in this study, and coincided with the highest tissue progesterone value. The tissue levels of oestradiol rose considerably at Day 12 in spite of an unchanged level of plasina progesterone (or oestradiol), but coincident with the decrease in tissue progesterone. When tissue progesterone decreased further (Day 18), tissue oestradiol increased. The decrease in tissue progesterone at Day 12 without any change in plasma progesterone might be due to a progesterone-induced decay of progesterone receptors as discussed previously (Thorbert et al., 1976). These results clearly indicate that the tissue oestradiol is influenced by progesterone and support the finding that progesterone reduces oestradiol receptors in the uterus (Jacobson, Keyes \& Bullock, 1972; West, Verhage \& Brenner, 1976). A similar interaction between oestradiol and progesterone after administration of steroids has recently been demonstrated for the rabbit uterus (Batra, Sjöberg \& Thorbert, 1978) and other reproductive tract tissues (Resko, Boling, Brenner \& Blandau, 1976).

The changes in uterine oestradiol metabolism during rabbit pregnancy might influence the concentration of oestradiol in this organ. However, the much increased activity of oestradiol dehydrogenase during pregnancy in the rabbit is due to oestradiol itself and not to an effect of progesterone (Jütting, 1970). It is therefore difficult to imagine how tissue oestradiol changes with no change in plasma oestradiol could be explained by a consideration of metabolic factors.

In a previous study we reported there was an inverse relationship between tissue progesterone and neuronal norepinephrine in the rabbit uterus (Thobert et al., 1976). Administration of oestradiol for 7 or 14 days markedly increases uterine norepinephrine content and this increase persists for at least 14 days without further treatment (Falck, Owman, Rosengren \& Sjöberg, 1969a). However, with a combined progesterone and oestradiol treatment uterine norepinephrine is reduced and returns to control values (Falck et al., 1969b). During pseuodpregnancy a marked decrease in uterine norepinephrine was observed on Days 3, 6, and 12, with the lowest level occurring on Day 6, coinciding with the peak in tissue progesterone (Thorbert et al., 1976). That observation, together with the present data, would suggest that the decreased level of nor- 
epinephrine which occurs in the rabbit uterus during pseudopregnancy is caused by the action of not only increased progesterone but also decreased oestradiol tissue concentrations.

This study was supported by the Ford Foundation (grants No. 640-0186 B and 680-0383 A) and the Swedish Medical Research Council (project No. 4781).

\section{References}

Batra, S. (1976) Unconjugated estradiol in the myometrium of pregnancy. Endocrinology 99, 11781181.

Batra, S. \& Bengtsson, L.Ph. (1976) A highly efficient procedure for the extraction of progesterone from uterus and its compatibility with subsequent radioimmunoassay. J. Steroid Biochem. 7, 599-603.

Batra, S., Sjöberg, N.-O. \& Thorbert, G. (1978) Estrogen and progesterone interactions in the rabbit uterus in vivo after steroid administration. Endocrinology 102 , $268-272$

Challis, J.R.G., Davies, I.J. \& Ryan, K.J. (1973) The concentrations of progesterone, estrone and estradiol$17 \beta$ in the plasma of pregnant rabbits. Endocrinology 93, 971-976.

Eaton, L.W. \& Hilliard, J. (1971) Estradiol-17ß, progesterone and 20a-hydroxy-pregn-4-en-3-one in rabbit ovarian venous plasma. I. Steroid secretion from paired ovaries with and without corpora lutea: effect of LH. Endocrinology 89, 105-111.

Falck, B., Owman, Ch., Rosengren, E. \& Sjöberg, N.-O. (1969a) Persisting high level of transmitter in uterine short adrenergic neurons following prolonged treatment with 17 $\beta$-oestradiol. Acta endocr., Copenh. 62, $77-81$.

Falck, B., Owman, Ch., Rosengren, E. \& Sjöberg, N.-O. (1969b) Reduction by progesterone of the estrogeninduced increase in transmitter level of the short adrenergic neurons innervating the uterus. Endocrinology 84, 958-959.

Hilliard, J. \& Eaton, L.W. (1971) Estradiol-17\%, progesterone and 20a-hydroxy-pregn-4-en-3-one in rabbit ovarian venous plasma. II. From mating through implantation. Endocrinology 89, 522-527.

Hilliard, J., Scaramuzzi, R.U., Penardi, R. \& Sawyer, C.H. (1974) Serum progesterone levels in hysterectomized pseudopregnant rabbit. Proc. Soc. exp. Biol. Med. 145, 151-153.

Jacobson, H.I., Keyes, P.L. \& Bullock, D.W. (1972)
Regulation of uterine estrogen receptor by luteal progesterone in pseudopregnant rabbit. Biol. Reprod. 7 , 108, Abstr.

Jütting, G. (1970) Hormonale Enzyminduktion im Myometrium-Beispiel einer Ostrogenwirkung am Erfolgsorgan. Acta endocr., Copenh. 64, Suppl. 145.

Lindberg, B.S., Lindberg, P., Martinsson, K. \& Johansson, E.D.B. (1974) Radioimmunological methods for the estimation of oestrone, oestradiol $17 \beta$ and oestradiol in pregnancy plasma. Acta obstet. gynec. scand. 5, Suppl. 32, 5-19.

Lowry, O.H., Rosebrough, H.J., Farr, A.L. \& Randall, R.J. (1951) Protein measurement with the folin phenol reagent. J. biol. Chem. 193, 265-275.

Powell, J.E.K. \& Stevens, V.C. (1973) Simple radioimmunoassay of five unconjugated ovarian steroids in a single sample of serum or plasma. Clin. Chem. 19, 210-215.

Resko, J.A., Boling, J.L., Brenner, R.M. \& Blandau, R.J. (1976) Sex steroids in reproductive tract tissues: regulation of estradiol concentrations by progesterone. Biol. Reprod. 15, 153-157.

Shaikh, A.A. \& Harper, M.J.K. (1972) Ovarian steroid secretion in estrous, mated and hCG-treated rabbits, determined by concurrent cannulation of both ovarian veins. Biol. Reprod. 7, 387-397.

Thorbert, G., Batra, S., Owman, Ch., Rosengren, E. \& Sjöberg, N.-O. (1976) Uterine norepinephrine levels as related to plasma and tissue progesterone in pseudopregnant rabbits. Endocrinology 99, 12071212.

West, N.B., Verhage, H.G. \& Brenner, R.M. (1976) Suppression of the estradiol receptor system by progesterone in the oviduct and uterus of the cat. Endocrinology 99, 1010-1016.

Wu, C.H., Blasco, L., Flickinger, G.L. \& Mikhail, G. (1977) Ovarian function in the preovulatory rabbit. Biol. Reprod. 17, 304-308.

Received 19 April 1978 